\title{
A Simple Method for the Alkylation of Diethyl Malonate
}

\author{
Shōta ITō, Norio SAitō, Kiyotaka Hatakeda and Takashi AsAno \\ The Government Industrial Research Institute, Tohoku (Nigatake, Haranomachi, Sendai)
}

Alkylmalonic esters, which have been recognized as important intermediates in the syntheses of various carboxylic acids, amino acids, etc., can be obtained by a variety of methods. ${ }^{1)}$ Excepting the introduction of tertiary alkyl groups, the alkylation of malonic esters with alkyl halides in basic conditions, for example, in ethanol in the presence of sodium ethoxide, is one of the most important and popular methods. In this paper, we wish to report a simple and facile method for the alkylation of diethyl malonate.

In connection with other work ${ }^{2}$, it was observed that diethyl malonate reacted with methyl iodide in $\mathrm{N}, \mathrm{N}$-dimethylformamide (DMF) solution in the presence of potassium carbonate to give colorless oil as a reaction product. This substance showed following spectral data; IR (liquid film) $1720 \mathrm{~cm}^{-1}$ (carbonyl group of ester) NMR $\left(\mathrm{CDCl}_{3}\right)$ (ppm) 4.10 $\left(4 \mathrm{H}, q, J=5.0 \mathrm{~Hz},-\mathrm{O}-\mathbf{C H}_{2}-\mathrm{CH}_{3}\right), 1.21(6 \mathrm{H}, t, J=$ $\left.5.0 \mathrm{~Hz},-\mathrm{CH}_{2}-\mathbf{C H}_{3}\right), 3.25(1 \mathrm{H}, q, J=7.5 \mathrm{~Hz}, \mathrm{ROOC}-$ $\left.\mathbf{C H}-\mathrm{CH}_{3}\right), 1.31\left(3 \mathrm{H}, \quad d, J=7.5 \mathrm{~Hz},-\mathrm{CH}_{1}-\mathbf{C H}_{3}\right)$. These data suggest that the colorless oil is diethyl methylmalonate. Furthermore, methylmalonic acid $\left(\mathrm{mp} 135^{\circ} \mathrm{C}\right)^{3)}$ was obtained by the mild hydrolysis of this substance. Thus the reaction product is undoubtedly diethyl methylmalonate.

After experimentation with various conditions, good yield (83\%) of diethyl methylmalonate was obtained when the mixture of diethyl malonate (1 equiv.), methyl iodide (2 equiv.), was refluxed for three hours in DMF in the presence of anhydrous potassium carbonate ( 1 equiv.). Sodium carbonate could be substituted for potassium carbonate without appreciably altering the reaction efficiency.
Some other diethyl alkylmalonates could be obtained by similar manner as shown in Table-1.

Recently it has been reported that the active methine group of 2-carboethoxy cyclopentanone could be alkylated with some alkyl halides in the presence of potassium carbonate in acetone.4) But the application of this method for the alkylation of diethyl malonate was unsuccessful.

Table-1 Alkylation of diethyl malonate with some alkyl halides in the presence of potassium carbonate.

$\mathrm{CH}_{2}\left(\mathrm{COOC}_{2} \mathrm{H}_{5}\right)_{2} \underset{\mathrm{K}_{2} \mathrm{CO}_{8}}{\stackrel{\mathrm{RX}}{\longrightarrow}} \mathrm{RCH}\left(\mathrm{COOC}_{2} \mathrm{H}_{5}\right)_{2}$

\begin{tabular}{c|c|c}
\hline Alkyl halide (RX) & Time (hr) & Yield (\%) \\
\hline $\mathrm{C}_{2} \mathrm{H}_{5} \mathrm{I}$ & 4 & 83 \\
$n-\mathrm{C}_{3} \mathrm{H}_{7} \mathrm{I}$ & 4 & 82 \\
$i-\mathrm{C}_{3} \mathrm{H}_{7} \mathrm{Br}$ & 5.5 & 79 \\
$n-\mathrm{C}_{4} \mathrm{H}_{9} \mathrm{I}$ & 4.5 & 82 \\
\hline
\end{tabular}

Although all of the reaction products are known compounds described in the references ${ }^{5) \sim 7}$, their structures were confirmed by the IR and NMR spectral analyses.

\section{References}

1) J. Oldham, "Rodd' s Chemistry of Carbon Compounds", Vol. ID, Elsvier Publishing, Amsterdam (1965) p. 301, and references cited therein.

2) S. Ito, N. Saito, K. Hatakeda and T. Asano, To be published shortly.

3) R. Meyer, P. Bock, Ann., 347, 100 (1906)

4) A. Barco, S. Benetti, G.P. Pollini, Synthesis, 1973 (5), 316

5) A. Michael, J. prakt. Chem., [2] 72, 547 (1905)

6) R. Adams, C.S. Marvel, J. Amer. Chem. Soc., 42, 316 (1920)

7) R. Adams, R.M. Kamm, “Org. Syn.," Coll., Vol. 1, p. 250 (1941), and references cited therein. 